\title{
Disentangling relationships among eastern Mediterranean Cymbalaria including description of a novel species from the southern Peloponnese (Greece)
}

\author{
Pau Carnicero ${ }^{1,2}$ (1) - Núria Garcia-Jacas ${ }^{3}$ (D) - Llorenç Sáez ${ }^{1,4}$ (1) $\cdot$ Theophanis Constantinidis $^{5}$ (1) \\ Mercè Galbany-Casals ${ }^{1}$ (iD
}

Received: 16 March 2020 / Accepted: 5 December 2020 / Published online: 4 February 2021

(C) The Author(s) 2021

\begin{abstract}
The eastern Mediterranean basin hosts a remarkably high plant diversity. Historical connections between currently isolated areas across the Aegean region and long-distance dispersal events have been invoked to explain current distribution patterns of species. According to most recent treatments, at least two Cymbalaria species occur in this area, Cymbalaria microcalyx and $C$. longipes. The former comprises several intraspecific taxa, treated at different ranks by different authors based on morphological data, evidencing the need of a taxonomic revision. Additionally, some populations of $C$. microcalyx show exclusive morphological characters that do not match any described taxon. Here, we aim to shed light on the systematics of eastern Mediterranean Cymbalaria and to propose a classification informed by various sources of evidence. We performed molecular phylogenetic analyses using ITS, 3'ETS, $n d h \mathrm{~F}$ and $r p l 32-t r n \mathrm{~L}$ sequences and estimated the ploidy level of some taxa performing relative genome size measures. Molecular data combined with morphology support the division of traditionally delimited $C$. microcalyx into $C$. acutiloba, $C$. microcalyx and $C$. minor, corresponding to well-delimited nrDNA lineages. Furthermore, we propose to combine C. microcalyx subsp. paradoxa at the species level. A group of specimens previously thought to belong to Cymbalaria microcalyx constitute a well-defined phylogenetic and morphological entity and are described here as a new species, Cymbalaria spetae. Cymbalaria longipes is non-monophyletic, but characterized by being glabrous and diploid, unlike other eastern species. The nrDNA data suggest at least two dispersals from the mainland to the Aegean Islands, potentially facilitated by marine regressions.
\end{abstract}

Keywords Aegean region $\cdot$ cpDNA $\cdot$ Dispersal $\cdot$ Marine barriers $\cdot$ Morphology $\cdot$ nrDNA

Handling Editor: Stanislav Španiel.

Contribution to "Plants of the Balkan Peninsula in Space and Time"

Supplementary Information The online version contains supplementary material available at (https://doi.org/10.1007/ s00606-020-01730-3).

Pau Carnicero

pau.carnicero@gmail.com

1 Systematics and Evolution of Vascular Plants (UAB) Associated Unit to CSIC, Departament de Biologia Animal, Biologia Vegetal i Ecologia, Facultat de Biociències, Universitat Autònoma de Barcelona, 08193 Bellaterra, Spain

\section{Introduction}

The eastern Mediterranean basin comprises two major centers of biodiversity, the Balkan-Aegean area with 6500-7000 species, of which ca. 1500 are endemic, and the

2 Department of Botany, University of Innsbruck, Sternwartestrasse 15, 6020 Innsbruck, Austria

3 Institut Botànic de Barcelona (IBB, CSIC-Ajuntament de Barcelona), Pg. del Migdia s/n, 08038 Barcelona, Spain

4 Societat d'Història Natural de les Balears (SHNB), C/Margarida Xirgu 16, 07011 Palma de Mallorca, Balearic Islands, Spain

5 Section of Ecology and Systematics, Department of Biology, National and Kapodistrian University of Athens, 15784 Panepistimiopolis, Athens, Greece 
Mediterranean part of the Anatolian Peninsula with ca. 5000 species, of which $30 \%$ are endemic (Thompson 2005). This richness is attributable to both moderate Pleistocene glaciation (Fady-Welterlen 2005; Wu et al. 2007) and a complex geography, with several mountain ranges and many islands (Polunin 1980; Thompson 2005). Furthermore, several species-rich Mediterranean lineages (e.g., Campanula L.: Roquet et al. 2009, Centaurea L. subgenus Centaurea: Hilpold et al. 2014; Haplophyllum A.Juss.: Manafzadeh et al. 2014) have significantly diversified there. Finally, a higher degree of single-island endemism compared to the western Mediterranean contributes to the high diversity and singularity of the eastern Mediterranean (Thompson 2005).

Cymbalaria Hill (Plantaginaceae) originated ca. 4 Ma in the central-eastern Mediterranean basin and rapidly diverged in three lineages (Carnicero et al. 2017), which further diverged in ten species and seven subspecies according to the most recent publications (Sutton 1988; Bigazzi and Raffaelli 2000; Carnicero et al. 2018, 2019). It is a genus of perennial herbs distributed throughout the Mediterranean basin, although most taxa are endemics of small areas. Cymbalaria species grow in rocky habitats in a wide range of ecological conditions, from coastal cliffs to rock crevasses in the subalpine belt. Ploidy levels vary across species ranging from diploids $(2 n=14)$ to octoploids $(2 n=56)$. Diploids mainly occur in the Apennine and Balkan Peninsulas, with one species in the eastern Mediterranean; tetraploids $(2 n=28)$ occur in Sicily, the Balkan Peninsula and the eastern Mediterranean basin, and a group of hexa- to octoploids $(2 n=42,56)$ occurs in Corsica, Sardinia and the Balearic Islands. Cymbalaria is a genus with intricate taxonomy in the eastern Mediterranean, where two out of the three main evolutionary lineages of the genus occur. Following Sutton (1988), two species occur in this area, the glabrous diploid C. longipes (Boiss. and Heldr.) A.Chev. and the hairy tetraploid C. microcalyx (Boiss.) Wettst. (Table 1). Cymbalaria longipes occurs in coastal areas from the Ionian Islands in the west to the Lebanon in the east (Fig. 1). There is little dispute about its taxonomic status due to some distinctive features, including 1) the characteristic habitat in cliffs and pebbles close to the sea; 2) glabrous vegetative organs; 3 ) big seeds that form a concrescent mass in an indehiscent capsule; and 4) diploidy ( $2 n=14$; Sutton 1988).

On the other hand, C. microcalyx is an aggregate of taxa with an intricate history of taxonomic combinations and description of new entities, all having in common the presence of hairy vegetative organs (e.g., Cufodontis 1936; Greuter 1979; Speta 1986). Cymbalaria microcalyx inhabits cliffs from the sea level up to ca. $2000 \mathrm{~m}$ (Maroulis and Georgiadis 2005) from the southern Balkan Peninsula to western Anatolia. Sutton (1988) recognized five subspecies, but also mentioned other entities, which could deserve taxonomic recognition. Speta (1986) instead took a more analytical perspective and recognized four species within the group (Table 1, Fig. 1); his work is taken here as a reference, with a single exception (Table 1), as it seems to better agree with available phylogenetic data (Carnicero et al. 2017). Indeed, Carnicero et al. (2017) showed that C. microcalyx sensu Sutton (1988) is non-monophyletic and its subspecies are found in three distinct clades, but the scarce sampling among the eastern species prevented further detailed taxonomic conclusions in that study. The westernmost species of the aggregate is C. ebelii (Cufod.) Speta, a narrow endemic of the surroundings of Skadar Lake at the border between Albania and Montenegro, distinguishable by unique oblong-ovoid seeds with a few scarcely anastomosed longitudinal ridges. Cymbalaria microcalyx s. str. (i.e., subsp. microcalyx) occurs in the Peloponnese and is characterized by unequally sized seeds, all with prominent wing-like ridges. Cymbalaria microcalyx subsp. heterosepala (Cufod.) Speta is endemic to western Crete, distinguishable from subsp. microcalyx because seeds form a concrescent mass in the capsule. Cymbalaria minor (Cufod.) Speta occurs in the Peloponnese and surrounding islands; it is characterized by small, equal-sized, alveolate seeds. A further taxon, C. acutiloba (Boiss. \& Heldr.) Speta, comprises two allopatric subspecies
Table 1 Two most relevant published taxonomic treatments for eastern Mediterranean Cymbalaria. Speta (1986) is taken here as a reference, with the exception of $C$. microcalyx subsp. paradoxa, not included in Speta (1986). Asterisks indicate taxa which were not formally accepted by Sutton (1988) but were mentioned as potentially good taxa

\begin{tabular}{ll}
\hline Speta (1986) & Sutton (1988) \\
\hline C. acutiloba subsp. acutiloba (Boiss. \& Heldr.) Speta & C. microcalyx subsp. acutiloba (Boiss. \& Heldr.) Greuter \\
C. acutiloba subsp. dodekanesi (Greuter) Speta & C. microcalyx subsp. dodekanesi Greuter \\
C. ebelii (Cufod.) Speta & C. microcalyx subsp. ebelii (Cufod.) Cufod. \\
C. longipes (Boiss. \& Heldr.) A.Chev. & C. longipes (Boiss. \& Heldr.) A.Chev. \\
C. microcalyx subsp. microcalyx (Boiss.) Wettst. & C. microcalyx subsp. microcalyx (Boiss.) Wettst. \\
C. microcalyx subsp. heterosepala (Cufod.) Speta & C. microcalyx var. heterosepala (Cufod.) Cufod.* \\
- & C. microcalyx subsp. paradoxa Greuter* \\
C. minor (Cufod.) Speta & C. microcalyx subsp. minor (Cufod.) Greuter \\
\hline
\end{tabular}




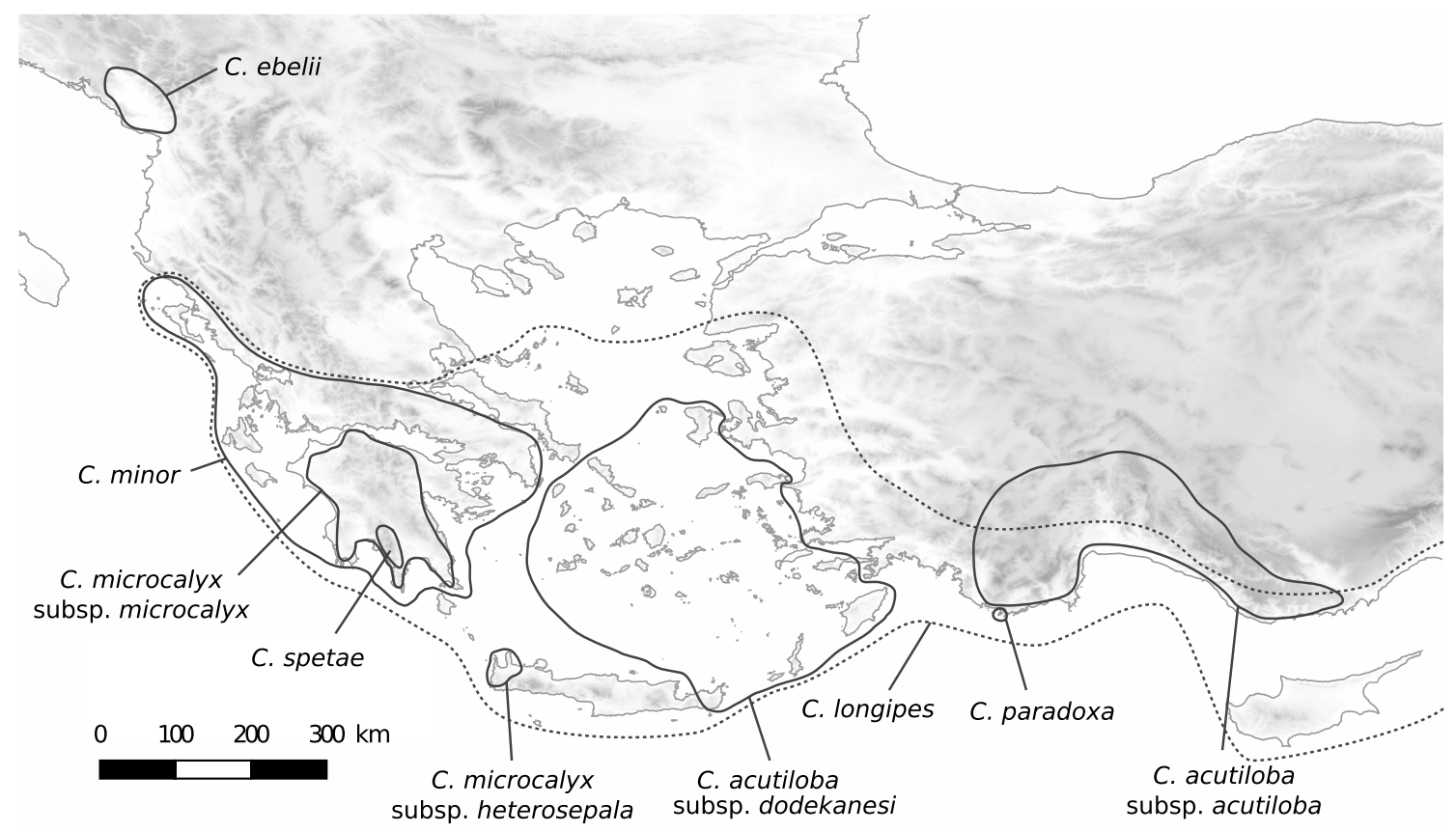

Fig. 1 Distribution of eastern Mediterranean Cymbalaria taxa, based on Sutton (1988), local Floras, personal field observations and herbarium vouchers. Names of most taxa follow Speta (1986) (Table 1), except for C. paradoxa and C. spetae (see "Taxonomic treatment")

with distinct seed morphology. Cymbalaria acutiloba subsp. acutiloba occurs in the mountains of southwestern Anatolia and bears unequally sized seeds with prominent wing-like ridges (Speta 1986; Sutton 1988). Cymbalaria acutiloba subsp. dodekanesi (Greuter) Speta is distributed throughout numerous Aegean Islands including the Cyclades, the eastern Aegean Islands, eastern Crete, Karpathos and Rhodes. Its seeds are cristate to alveolate, not-winged and heterogeneous in size.

Finally, C. microcalyx subsp. paradoxa Greuter, a narrow endemic from Kastellorizo island, is densely hairy and has a similar seed morphology as $C$. longipes (i.e., big seeds that form a concrescent mass in an indehiscent capsule). Sutton (1988) did not study it in depth, and this taxon was not included in Speta (1986), but it was listed as accepted taxon in the last checklist of the Flora of Greece (Dimopoulos et al. 2013), similarly as C. microcalyx subsp. alba (Voliotis) Kit Tan. The latter is a Peloponnese endemic that allegedly differs from C. microcalyx subsp. microcalyx by its white flowers, longer spur and smaller calix (Voliotis 1990, Tan and Iatrou 2001). With respect to ploidy level, the available data suggest that $C$. microcalyx subsp. microcalyx, C. ebelii, $C$. acutiloba subsp. dodekanesi, and C. minor are tetraploid (Speta 1986, 1989; Sutton 1988; P. Carnicero unpubl. data). The role of polyploid speciation in the genus has been previously highlighted (Carnicero et al. 2017), but it remains uncertain how is it involved in the divergence of the taxa of this particular group.
During our studies on the genus Cymbalaria, two specimens kept in the herbaria SALA and MA and identified as $C$. microcalyx caught our attention. Both were collected from the same locality in the mountain range Taigetos (southern Peloponnese) and differ in several characters from any taxon described in the region, i.e., the higher number of leaf lobes, big flowers with a short and wide spur, and small cristate-alveolate seeds. During field work we found a second population showing the same characters. The morphological features suggest that this entity deserves taxonomic recognition, and it is expected that molecular and ploidy level data will help to determine its evolutionary history and taxonomic rank.

The high number of infraspecific taxa described within eastern Mediterranean Cymbalaria species, the incongruence in taxonomic treatments between authors and the existence of populations non-attributable to any described taxon, strongly emphasizes the need of a comprehensive systematic study combining molecular, morphological and ploidy data to clarify the taxonomy of the group. Moreover, the current distribution of eastern Mediterranean Cymbalaria species, which is strongly fragmented and spans major biogeographic barriers such as Rechinger's line (Rechinger 1943, 1950; Strid 1996), suggests that this group is well suited to improve our understanding of plant evolution and biogeography in the eastern Mediterranean.

Using a combination of plastid (cpDNA) and nuclear ribosomal (nrDNA) sequences, morphological data and relative genome size, we aim to clarify the systematics of eastern 
Mediterranean Cymbalaria species. Specifically, we aim to test whether the populations from Taigetos, previously considered $C$. microcalyx, belong to a new taxon and to determine its phylogenetic affinities. Finally, we aim to provide first insights into the group's spatial diversification in order to contribute new data to Aegean plant biogeography.

\section{Materials and methods}

\section{Plant material}

We sampled at least one specimen of all described species of Cymbalaria, with the aim of building a complete phylogenetic backbone to infer the phylogenetic position of the eastern Mediterranean taxa. The latter were more intensively sampled with the aim of studying their phylogenetic relationships and to capture as much geographic and genetic variation as possible. In total, 65 specimens were used in molecular analyses, of which 28 specimens belonging to eastern Mediterranean taxa were sequenced for the present study. The relative genome size was determined for seven specimens, and 62 were used for morphological studies. Sampling localities, voucher details, as well as specimens used in each analysis, are provided in Online Resource 1. Asarina procumbens Mill. was used as outgroup, based on previous studies (Ghebrehiwet et al. 2000; Vargas et al. 2004; Guzmán et al. 2015; Carnicero et al. 2017).

\section{DNA extraction, amplification and sequencing}

Total genomic DNA was extracted from ca. 10 to $30 \mathrm{mg}$ silica gel-dried leaf material or herbarium vouchers following a CTAB protocol (Doyle and Doyle 1987) with some modifications (Tel-Zur et al. 1999). When less than $10 \mathrm{mg}$ of dried material was available, no sorbitol washing was applied.

We amplified the ITS region and the conserved 3'ETS region of the nuclear ribosomal DNA (nrDNA), as well as the $n d h \mathrm{~F}$ region and the $r p l 32-t r n \mathrm{~L}^{U A G}$ spacer of the plastid DNA (cpDNA). We used the primers ITS1 and ITS4 (Sun et al. 1994) for ITS, the primers Ast1F and 18SETS (Markos and Baldwin 2001) for 3'ETS, the primers 3'F (Eldenäs et al. 1999) and +607 (Kim and Jansen 1995) and the internal primers ndhF CymbF and ndhF CymbR (Carnicero et al. 2017 ) for $n d h \mathrm{~F}$, and the primers rpl32F and trnL ${ }^{\mathrm{UAG}}$ (Shaw et al. 2007) for $r p l 32-t r n L$. The profile used for amplification of ITS included 4-min denaturation at $95{ }^{\circ} \mathrm{C}$, followed by 30 cycles of 90 -s denaturation at $94{ }^{\circ} \mathrm{C}, 2$-min annealing at $55^{\circ} \mathrm{C}$ and 3 -min extension at $72{ }^{\circ} \mathrm{C}$, with an additional final step of $15 \mathrm{~min}$ at $72{ }^{\circ} \mathrm{C}$. The profile used for amplification of the rpl32-trn $\mathrm{L}^{U A G}$ spacer included 3-min denaturation at $94{ }^{\circ} \mathrm{C}$, followed by 30 cycles of 40 -s denaturation at $95^{\circ} \mathrm{C}$, 2-min annealing at $52{ }^{\circ} \mathrm{C}$ and 2 -min extension at $72{ }^{\circ} \mathrm{C}$, with an additional final step of $10 \mathrm{~min}$ at $72{ }^{\circ} \mathrm{C}$. We followed the PCR profiles described in Galbany-Casals et al. (2009) for ETS and Galbany-Casals et al. (2012) for $n d h$ F. Direct sequencing was conducted by the Macrogen Sequencing Service (Seoul, South Korea). See Online Resource 1 for information on the vouchers and the sequences.

\section{Phylogenetic analyses}

The sequences were first examined and edited using Mega 6.06 (Tamura et al. 2013) and Finch TV 1.4 (Geospiza). Sequences were initially aligned using Clustal X 2.0.9 (Larkin et al. 2007) and adjusted manually in Mega 6.06. Ambiguous regions in the cpDNA alignment were detected and excluded using Gblocks v.0.91 (Castresana 2000; Talavera and Castresana 2007) with relaxed conditions in order to preserve as much information as possible: "Minimum Number Of Sequences For A Conserved Position" and "Minimum Number Of Sequences For A Flank Position" were half the number of sequences, "Minimum Number Of Contiguous Nonconserved Positions" was 5, "Maximum Number Of Contiguous Nonconserved Positions" was 10, "Minimum Length Of A Block" was 5, and "Allowed Gap Positions" was "With Half." We kept the entire nrDNA matrix since we detected no ambiguously aligned regions after visual inspection. Indels were coded as binary characters using the simple indel coding method (Simmons and Ochoterena 2000). The ITS region and the conserved 3'ETS region were concatenated in a single nrDNA matrix, as were the $n d h \mathrm{~F}$ region and the rpl32-trn $\mathrm{L}^{U A G}$ spacer in a single cpDNA matrix. Plastid and nrDNA matrices were analyzed separately due to the phylogenetic incongruence found between the two genomes (see "Results").

Maximum Parsimony (MP) analyses were conducted with PAUP*v.4.0a149 (Swofford 2002) for both cpDNA and nrDNA datasets. We performed 10,000 replicates of heuristic searches with random taxon addition and tree bisectionreconnection (TBR) branch swapping and retaining all most parsimonious trees; uninformative characters were excluded. The bootstrap analyses were performed with 1000 replicates, TBR branch swapping and random taxon addition with 10 replicates. Consistency Index (CI), Retention Index (RI) and Homoplasy Index (HI) were calculated from the consensus tree (Online Resource 2).

PartitionFinder (Lanfear et al. 2012) was used to find the best model of evolution and the best partitioning scheme under the Bayesian information criterion (BIC; Schwarz 1978 ) for the Bayesian inference (BI) analyses. The models tested were those implemented in MrBayes. A greedy search algorithm was selected for running the analysis for each dataset. Single partitions were found for the $\mathrm{cp}$ and nrDNA, respectively, and therefore, no partitions were 
defined in further analyses. The BI analysis was conducted with MrBayes v.3.2 (Ronquist et al. 2012). Coded indels were defined as separate partitions and analyzed with the restriction site (binary) model, as recommended by the program developers (Ronquist et al., 2020). We generated 10,000 trees running MrBayes for 5,000,000 generations and sampling one of every 500 generations. After ensuring that the Monte Carlo Markov chain (MCMC) reached stationarity and that the two runs converged by checking the standard deviation of split frequencies and the potential scale reduction factor, we discarded the first 2500 trees as burn-in.

\section{Morphological analyses}

Twelve characters (six vegetative and six reproductive) were scored on the basis of previous studies on Cymbalaria and the tribe Antirrhineae (Sutton 1988; Sáez and Crespo 2005; Vigalondo et al. 2015; Carnicero et al. 2018) and the observed variability within the studied taxa (Table 2). Two extra characters were calculated as ratios of different corolla size characters, in order to summarize information on the shape of the corolla. For the vegetative characters, three measurements per specimen were averaged when possible. Five semiquantitative indumentum characters were examined under a binocular stereoscopic microscope. The remaining characters were measured on scanned specimens using ImageJ (Abràmoff et al. 2004). Unfortunately, C. microcalyx subsp. heterosepala was not included in the analyses because flowers were not available in the specimens examined. Cymbalaria ebelii was excluded from quantitative analyses due to its clear differentiation using seed characters (Speta 1986, 1989), its phylogenetic position (Carnicero et al. 2017, and results of the present paper) and previous studies pointing to its divergence from C. microcalyx (Cufodontis 1936, 1947; Speta 1986). The final dataset comprised 62 specimens from 37 populations (see Online Resources 1 and 3). Sixty-nine additional herbarium specimens were also examined for the purpose of building the identification key (see Online Resource 3).

Quantitative analyses were conducted using a set of $\mathrm{R}$ functions contained in MorphoTools ver. 1.01 (Koutecký 2015). Pearson's and Spearman's correlation coefficients were computed to reveal correlation structure among the characters and to ensure that no strong correlations $(>|0.9|)$ were present. After standardization to zero mean and unit variance, principal component analysis (zero-centered PCA based on a covariance matrix) was applied to display the overall variation pattern along the first two components.

Five seed characters were studied under a binocular stereoscopic microscope and scored (Table 2), but they were excluded from the morphometric analysis due to the high amount of missing data. Scanning electron microscopic (SEM) images were taken with the aim to better describe and illustrate the observed differences in testa sculpturing of the seeds. We analyzed mature seeds of a subset of six specimens, with special focus on taxa lacking seed micrographs in

Table 2 Morphological characters studied

\begin{tabular}{ll}
\hline Character & Type \\
\hline Corolla length $(\mathrm{mm})$ & Quantitative \\
Corolla tube width $(\mathrm{mm})$ & Quantitative \\
Spur length $(\mathrm{mm})$ & Quantitative \\
Spur width $(\mathrm{mm})$ & Quantitative \\
Ratio spur length $(\mathrm{mm}) /$ corolla width $(\mathrm{mm})$ & Quantitative (ratio) \\
Ratio spur length $(\mathrm{mm}) /$ spur width $(\mathrm{mm})$ & Quantitative (ratio) \\
Calyx length $(\mathrm{mm})$ & Quantitative \\
Indumentum of stem & Semiquantitative $(0=$ glabrous; $1=$ subglabrous, sparsely distributed \\
Indumentum of adaxial leaf surface & hairs; $2=$ non-overlapping, uniformly distributed hairs; $3=$ overlap- \\
Indumentum of abaxial leaf surface & ping hairs; $4=$ lanate $)$ \\
Indumentum of calyx & \\
Indumentum of upper part of pedicel & \\
Number of leaf lobes & \\
Maximum leaf width $(\mathrm{mm})$ & Quantitative \\
Number of seeds/capsule* & Quantitative \\
Heterocarpy* & Quantitative \\
Concrescence of seeds * & Qualitative \\
Testa sculpturing* & Qualitative \\
Seed length (mm)* & Qualitative \\
\hline
\end{tabular}

* Characters excluded from the analyses due to the high amount of missing data 


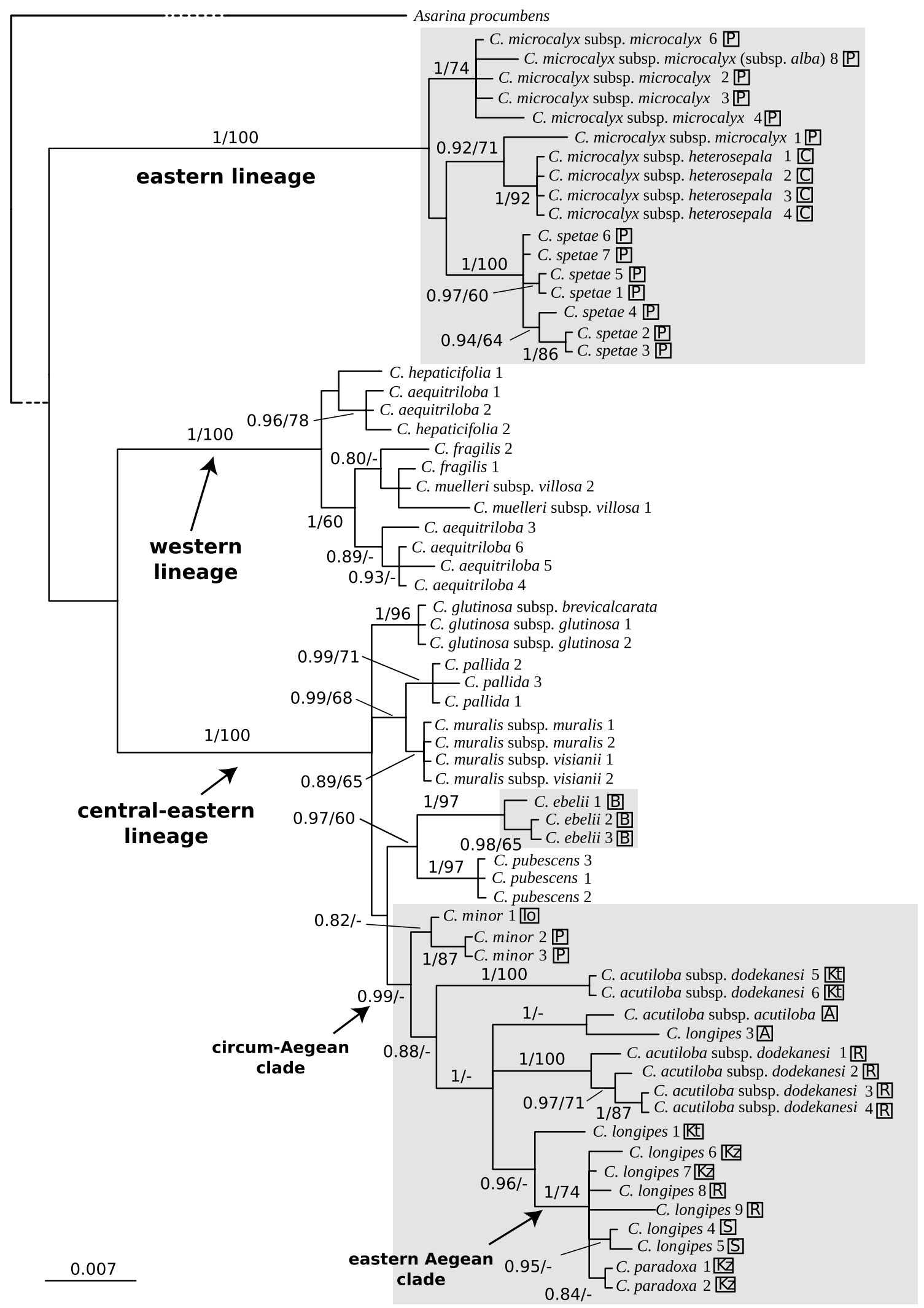


४Fig. 2 Bayesian inference phylogram of Cymbalaria derived from the concatenated nrDNA matrix (ITS and 3'ETS). Dotted lines indicate branches that have been manually shortened. Bayesian posterior probabilities $\geq 0.80$ /bootstrap support values $\geq 60 \%$ are indicated. Names of eastern taxa follow Speta (1986) (Table 1), except for $C$. paradoxa and $C$. spetae (see "Taxonomic treatment"). The non-accepted taxon C. microcalyx subsp. alba is indicated in parentheses. Gray boxes indicate clades composed only by eastern Mediterranean species. Letters next to the species names indicate the geographic origin of eastern Mediterranean specimens ( $A$ Anatolia, $B$ Balkans, $C$ Crete, $K t$ Karpathos, $K z$ Kastelorizo, $P$ Peloponnese, $R$ Rhodes, $S$ Samos)

previous studies (i.e., C. ebelii, C. microcalyx subsp. paradoxa, C. microcalyx subsp. heterosepala and the putative new taxon from Taigetos). Material was glued on SEM aluminum stubs and sputter-coated with 40-50-nm gold. Samples were examined with an Evo MA 10 Scanning Electron Microscope (Zeiss) at 15-25 kV. Terminology of seed shape and testa sculpturing follows Sutton (1988).

\section{Flow cytometry}

Relative genome size (RGS) measurements were taken with the aim of inferring the ploidy level of taxa without published chromosome counts. However, due to the lack of fresh mature seeds able to germinate and the low quality of measurements performed on dry leaf material, only four taxa were analyzed. Fresh leaf material of germinated seeds from C. microcalyx subsp. paradoxa and the putative new taxon from Taigetos was used (Online Resource 1). Additionally, C. microcalyx subsp. microcalyx and C. acutiloba subsp dodekanesi were measured in order to confirm previously documented ploidy levels (Sutton 1988; P. Carnicero unpubl. data). Diploid $C$. muralis G.Gaertn., B.Mey. \& Scherb. from the Botanical Garden of the University of Innsbruck, was also measured as a reference. Flow cytometry (FCM) of 4',6-diamidino-2-phenylindole (DAPI; final concentration b $0.036 \mathrm{M}$ )-stained nuclei was used to estimate RGS and to assess DNA ploidy levels (Suda and Trávníček 2006). The standard used to determine DNA amounts was Solanum pseudocapsicum L. $(2 \mathrm{C}=2.58 \mathrm{pg}$; Temsch and Greilhuber 2010). Fresh leaf tissue was chopped with leaf material of the standard and processed as described in Suda et al. (2007). The relative fluorescence intensity of 3000 particles was recorded using a Partec CyFlow Space flow cytometer (Partec GmbH, Münster, Germany). Partec FloMax software was used to evaluate the histograms, which were manually gated. RGS was calculated as ratio between the relative fluorescence of sample and standard. The reliability of the measurements was assessed by calculating coefficients of variation $(\mathrm{CV})$ for the $\mathrm{G} 1$ peaks of both the analyzed sample and the reference standard. Analyses yielding a CV threshold of $>5 \%$ were discarded, and the samples measured again. Ploidy levels were estimated by comparing RGS of samples with that of diploid C. muralis ( $2 n=14$; Sutton 1988).

\section{Results}

\section{Phylogenetic analyses}

The analyses of the nrDNA with MP and BI resulted in congruent phylogenetic tree topologies and retrieved three main lineages (Fig. 2). The eastern Mediterranean Cymbalaria taxa appeared in two of these three lineages. One was composed exclusively by eastern Mediterranean species (eastern lineage; $\mathrm{BS}=100 \%, \mathrm{PP}=1$ ), and a second one was composed of central and eastern Mediterranean species (central-eastern lineage; $\mathrm{BS}=100 \%, \mathrm{PP}=1$ ). The eastern lineage contained three main clades. One comprised specimens of $C$. microcalyx subsp. microcalyx (including C. microcalyx subsp. alba, $\mathrm{BS}=74 \%, \mathrm{PP}=1$ ); a second clade consisted of all specimens of C. microcalyx subsp. heterosepala and one specimen of C. microcalyx subsp. microcalyx $(\mathrm{BS}=92 \%, \mathrm{PP}=1)$; and the third one comprised the specimens of uncertain identity from Taigetos (named C. spetae in trees, $\mathrm{BS}=100 \%, \mathrm{PP}=1$ ). Relationships among these three mains clades as well as with one specimen of C. microcalyx subsp. microcalyx in the eastern lineage received low statistical support. Within the centraleastern lineage, $C$. ebelii formed a clade $(\mathrm{BS}=97 \%, \mathrm{PP}=1)$ sister to $C$. pubescens (C.Presl) Cufod., a species endemic to Sicily (BS $=60 \%, \mathrm{PP}=0.97$ ), and the remaining eastern species constituted an independent monophyletic group (CircumAegean Clade, PP=0.99). Within the Circum-Aegean Clade, the basal branches had low statistical support. Cymbalaria acutiloba subsp. dodekanesi formed two supported clades constituted by the specimens from Karpathos (specimens 5 and $6, \mathrm{BS}=100 \%, \mathrm{PP}=1$ ) and by the specimens from Rhodes (specimens $1-4, \mathrm{BS}=100 \%, \mathrm{PP}=1$ ), respectively, but these two clades did not group together. Instead, specimens 1-4 grouped with $C$. longipes, $C$. acutiloba subsp. acutiloba and C. microcalyx subsp. paradoxa (C. paradoxa in the tree, according to the final taxonomic treatment proposed here, see "Taxonomic treatment"). Besides the $C$. acutiloba subsp. dodekanesi clades, two supported clades congruent with geography were found: 1) C. longipes 3 and C. acutiloba subsp. acutiloba, both from Anatolia $(\mathrm{PP}=1)$ and 2) C. longipes 1, 4-9 and $C$. paradoxa, all from the Aegean Islands $(\mathrm{PP}=96)$. Within the latter, all the specimens from the eastern Aegean Islands formed a subclade (the Eastern Aegean Clade, $\mathrm{BS}=74 \%, \mathrm{PP}=1$ ).

In the cpDNA analyses, Cymbalaria was divided into two clades (Fig. 3). The first main clade grouped a subclade of all the specimens of uncertain identity from Taigetos ( $\mathrm{BS}=96 \%, \mathrm{PP}=1)$ with some of the central Mediterranean species $(\mathrm{BS}=79 \%, \mathrm{PP}=1)$, and the second main clade grouped all remaining Cymbalaria specimens, although with low statistical support $(\mathrm{PP}=0.94)$. Statistical supports for the basal branches in the second clade were generally 
Fig. 3 Bayesian inference phylogram of Cymbalaria derived from the concatenated cpDNA matrix ( $n d h \mathrm{~F}$ and rpl32-trnL$U A G$ ). Bayesian posterior probabilities $\geq 0.80$ /bootstrap support values $\geq 60 \%$ are indicated. Names of most taxa follow Speta (1986) (Table 1), except for C. paradoxa and C. spetae (see Taxonomic treatment). The non-accepted taxon C. microcalyx subsp. alba is indicated in parentheses. Letters next to the species names indicate the geographic origin of eastern Mediterranean specimens $(A$ Anatolia, $B$ Balkans, $C$ Crete, $K t$ Karpathos, $K z$ Kastelorizo, $P$ Peloponnese, $R$ Rhodes, $S$ Samos)

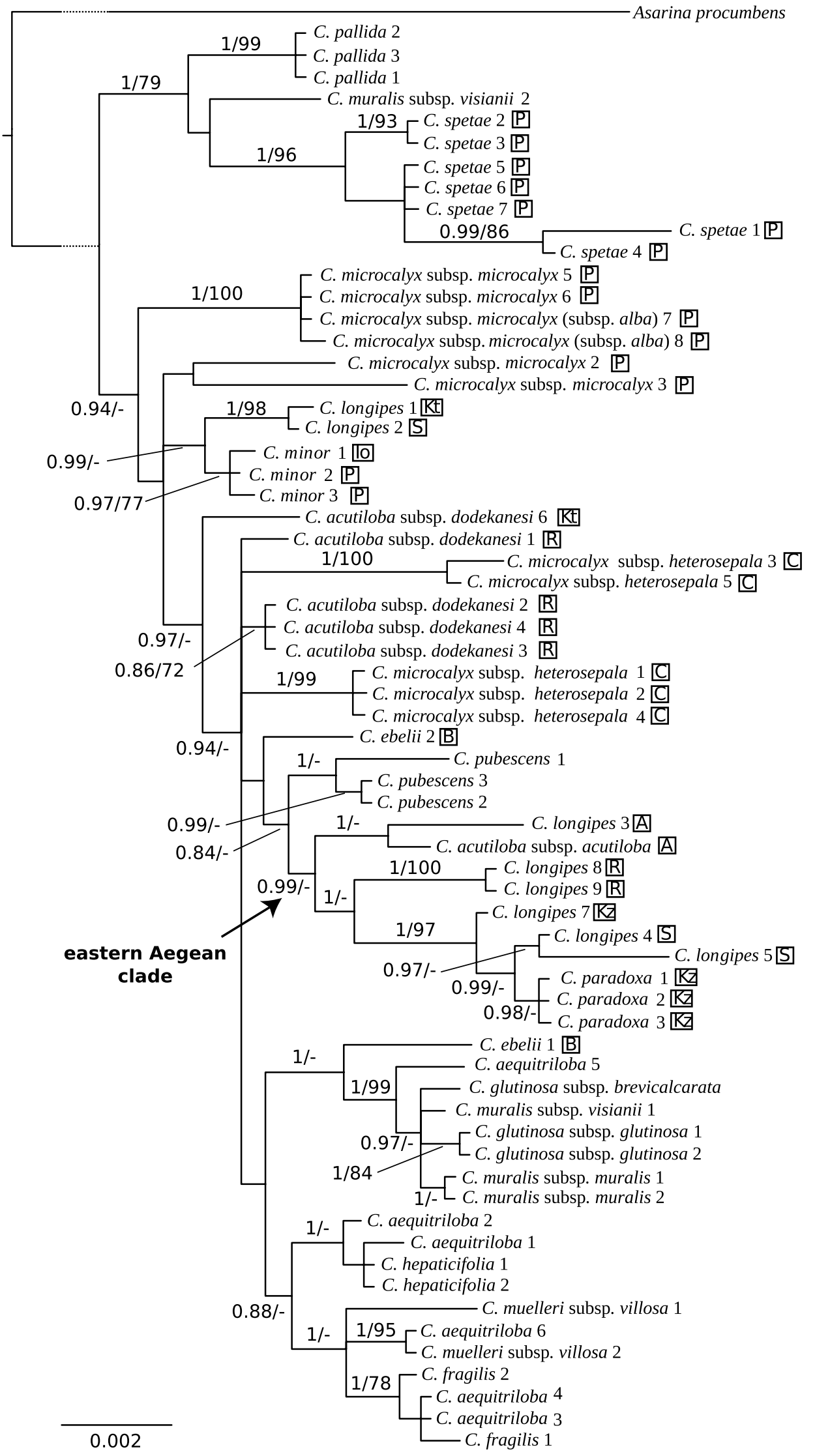


low. Within the eastern taxa, only C. minor and C. paradoxa (three specimens from a single population) were monophyletic ( $\mathrm{BS}=77 \%, \mathrm{PP}=0.97$ and $\mathrm{PP}=0.98$, respectively). Most eastern taxa were split in two or more clades. The most remarkable relationships congruently inferred based on nrDNA and cpDNA were: 1) the monophyletic specimens from Taigetos; and 2) the Eastern Aegean Clade $(\mathrm{PP}=0.99)$. Cymbalaria longipes 1 clustered with $C$. longipes $2(\mathrm{BS}=98 \%, \mathrm{PP}=1)$, and this clade was sister to $C$. minor $(\mathrm{PP}=0.99)$.

\section{Morphological analyses}

Correlation coefficients did not exceed 0.95 for any pair of characters; therefore, all characters were retained for further analyses (Table 2). In the PCA, the first axis accounted for $50 \%$ of the variation and the second axis for $17 \%$. The ordination diagram (Fig. 4a) showed a strong separation of the specimens of uncertain identity from Taigetos (named C. spetae in the figure) from the remaining eastern species. Its clear divergence is illustrated with boxplots for the characters Calyx length and ratio spur length/corolla length (Fig. 4b, c). Cymbalaria longipes also constituted a welldelimited group. Cymbalaria microcalyx s. 1. specimens formed a cloud with less clear separation among infraspecific entities. However, three groups with limited overlap could be observed: 1) C. acutiloba subsp. acutiloba and C. microcalyx subsp. paradoxa (C. paradoxa in the figure, according to the final taxonomic treatment proposed here); 2) C. minor and C. acutiloba subsp. dodekanesi; and 3) C. microcalyx subsp. microcalyx (including subsp. alba).

The examination of seeds under the binocular stereoscopic microscope, SEM images (Fig. 5) and previous studies (Speta 1986, 1989; Sutton 1988) supported the groups visualized in the PCA. Details on seed morphology are summarized in Table 3.

\section{Flow cytometry}

Mean RGS for the known tetraploids $C$. acutiloba subsp. dodekanesi and C. microcalyx subsp. microcalyx were 0.63 (0.62-0.64) and 0.60, respectively. Both exhibited, respectively, 3.15 and 2.99 times the monoploid RGS of the diploid $C$. muralis, although chromosome counts confirmed them as tetraploids (Speta 1986; Carnicero unpubl. data). The specimens of uncertain identity from Taigetos and $C$. paradoxa showed a mean RGS of 0.61 and 0.7 (0.70-0.71), respectively, 3.1 and 3.5 times the monoploid RGS of the diploid $C$. muralis. Since the ratios to $C$. muralis are close to those shown by the two known tetraploids, we speculate that they both are likely tetraploids. All the tetraploid RGS values measured here are lower than expected if genome size increased in direct proportion with polyploidy, which can be

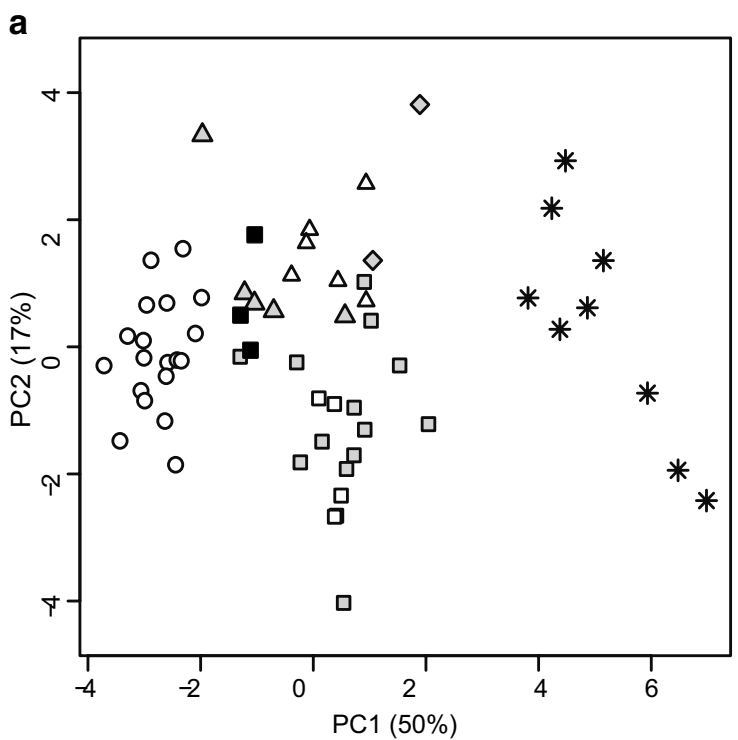

$\Delta$ C. acutiloba subsp. acutiloba $\quad$ C. paradoxa

$\Delta$ C. acutiloba subsp. dodekanesi $\square$ C. microcalyx subsp. microcalyx

○ C. longipes

ㄷ. microcalyx subsp. alba

$\diamond$ C. minor

* C. spetae
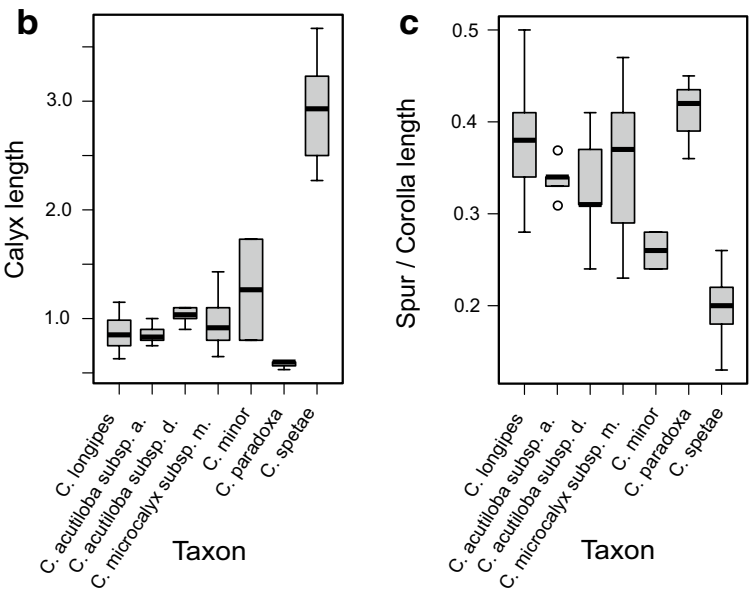

Fig. 4 Morphological analyses of eastern Mediterranean Cymbalaria. Names of most taxa follow Speta (1986) (Table 1), except for $C$. paradoxa and $C$. spetae (see Taxonomic treatment). a Principal component analysis of fourteen floral and vegetative characters obtained for 62 specimens of eastern Mediterranean Cymbalaria taxa. The non-accepted taxon $C$. microcalyx subsp. alba is included as a separate entity in the legend to show its lack of morphological differentiation from $C$. microcalyx subsp. microcalyx. b, c Boxplots showing median, upper and lower quartiles, minimum and maximum values (excluding outliers) and outliers for the two characters showing the greatest differences between Cymbalaria spetae and other eastern Mediterranean taxa

explained by heterogeneity in the monoploid genome size across the studied species and genome downsizing, an often reported phenomenon in non-recently formed polyploids (Leitch and Bennett 2004; Frajman et al. 2015; Lazarević et al. 2015). 
Fig. 5 Scanning electron micrographs of seeds of eastern Mediterranean Cymbalaria taxa. Cymbalaria microcalyx subsp. heterosepala, Greece: Crete, Falasarna, cape above ruins, $50 \mathrm{~m}$, cracks in limestone rocks, cliffs above the sea, $P$. Carnicero 1022 (BC 975713), $\mathbf{a}, \mathbf{b}$ whole seed; $\mathbf{c}$ base of ridges and interstitial region; $C$. microcalyx subsp. microcalyx, Greece: Peloponnese, Lakonia, Mystras, gorge, trail to Taygeti, 400-430 m, cracks in limestone cliffs facing $\mathrm{N}$ and shady boulders, P. Carnicero 1063 (BC 975709), d whole seed; e ridge; $\mathbf{f}$ base of ridges and interstitial region; C. microcalyx subsp. paradoxa, Greece: Kastelorizo, above Megisti, stairs on the way up to the cliff, 100-130 m, cracks in limestone rocks facing N, P. Carnicero 1039 (BC 975705), g 2-3 seeds forming a concrescent mass; $\mathbf{h}$ ridge; $\mathbf{i}$ interstitial region; $C$. acutiloba subsp. dodekanesi, Greece: Rhodes, Arkangelos, Mount Profitis Ilias S of village, following the road toward the hermitage, $430 \mathrm{~m}$, cracks in limestone cliff facing NW, $P$. Carnicero 1062 (BC 975702), $\mathbf{j}$ whole seed (basal); $\mathbf{k}$ whole seed (others); $\mathbf{l}$ ridges and interstitial zone; C. spetae, Greece: Peloponnese, Lakonia, Trypi, road to Kalamata, tunnel excavated in the rock, $780 \mathrm{~m}$, cracks in shady limestone rocks, $P$. Carnicero 1074 (BC 955798), $\mathbf{m}$ whole seed; $\mathbf{n}$ ridges and interstitial zone; $\mathbf{o}$ interstitial zone; C. ebelii, Montenegro: Skadarsko Jezero, Virpazar, P. Janackovic (BC 975708), p whole seed; $\mathbf{q}, \mathbf{r}$ seed surface details
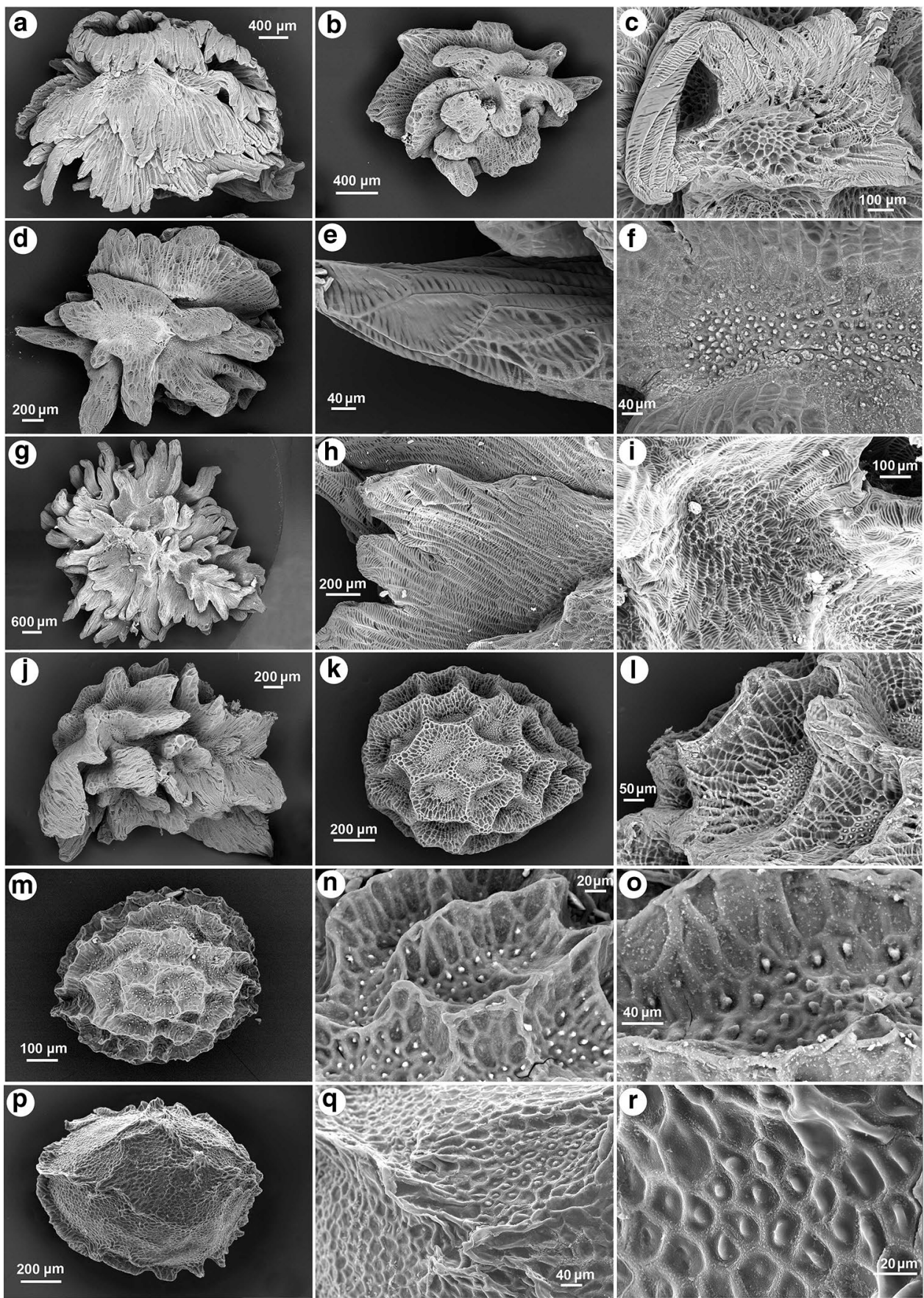

\section{Discussion}

Our study recovered the same early divergent lineages for the genus Cymbalaria reported in Carnicero et al. (2017) and confirm that the eastern taxa are in comparison more phylogenetically diverse than the central and western species, by occurring in two out of the three main lineages (Fig. 2). Our extended molecular sample and the addition of morphological data, allow us to confirm that the most recent taxonomic treatment of the genus (Sutton 1988), adopted by recent publications (e.g., Dimopoulos et al. 2013), underestimate the extant diversity of the eastern Mediterranean Cymbalaria and should therefore be updated. With the notable exception of a hitherto unrecognized species, which we formally describe below, our data largely support Speta's (1986) taxonomic treatment for the group, i.e., the recognition of $C$. longipes and the split of a variable and widely distributed C. microcalyx (sensu Sutton 1988; Dimopoulos et al. 2013), into at least three groups. These correspond to (1) C. ebelii, (2) C. microcalyx as well as (3) a group 
Table 3 Seed characters and ploidy level of studied species. Names of taxa follow Speta (1986) (Table 1) with the exception of Cymbalaria paradoxa and C. spetae (see Taxonomic treatment)

\begin{tabular}{|c|c|c|c|c|c|c|}
\hline Taxon & $\begin{array}{l}\text { Chromosome } \\
\text { number }\end{array}$ & $\begin{array}{l}\text { Number of } \\
\text { seeds/cap- } \\
\text { sule }\end{array}$ & $\begin{array}{l}\text { Seed length range } \\
\text { (smallest and biggest } \\
\text { seed observed, } \mathrm{mm} \text { ) }\end{array}$ & $\begin{array}{l}\text { Seeds equal in size/ } \\
\text { disposition within the } \\
\text { capsule }\end{array}$ & $\begin{array}{l}\text { Concres- } \\
\text { cence of } \\
\text { seeds }\end{array}$ & Testa \\
\hline $\begin{array}{l}\text { C. acutiloba subsp. } \\
\text { acutiloba }\end{array}$ & Unknown & Few $^{1}$ & $2-3^{1}$ & Unequal/irregular & Unknown & $\begin{array}{l}\text { Irregularly cristate, } \\
\text { ridges wing-like, } \\
\text { with numerous trian- } \\
\text { gular tips }\end{array}$ \\
\hline $\begin{array}{l}\text { C. acutiloba subsp. } \\
\text { dodekanesi }\end{array}$ & $2 n=28^{3,5}$ & $8-14$ & $0.9-3.3$ & $\begin{array}{l}\text { Unequal/decreasing } \\
\text { toward the apex }\end{array}$ & No & $\begin{array}{l}\text { Basal seeds irregularly } \\
\text { cristate, ridges wing- } \\
\text { like with rounded } \\
\text { apex; otherwise } \\
\text { alveolate, ridges not } \\
\text { wing-like }\end{array}$ \\
\hline C. ebelii & $2 n=28^{4}$ & $2-10^{4}$ & $1.5-2.5$ & Equal & No & $\begin{array}{l}\text { Cristate, ridges low } \\
\text { and scarce, scarcely } \\
\text { anastomosed, not } \\
\text { wing-like }\end{array}$ \\
\hline C. longipes & $2 n=14^{2}$ & $2-6^{2}$ & $3.5-5.6$ & Unequal/irregular & Yes & $\begin{array}{l}\text { Irregularly cristate, } \\
\text { ridges wing-like with } \\
\text { rounded apex, deeply } \\
\text { divided in digitate } \\
\text { expansions }\end{array}$ \\
\hline $\begin{array}{l}\text { C. microcalyx subsp. } \\
\text { microcalyx }\end{array}$ & $2 n=28^{1,3}$ & $4-10$ & $1.3-4$ & Unequal/irregular & No & $\begin{array}{l}\text { Irregularly cristate, } \\
\text { ridges wing-like with } \\
\text { rounded apex }\end{array}$ \\
\hline $\begin{array}{l}\text { C. microcalyx subsp. } \\
\text { heterosepala }\end{array}$ & Unknown & $4-6$ & $2.2-4.8$ & Unequal/irregular & Yes & $\begin{array}{l}\text { Irregularly cristate, } \\
\text { ridges wing-like } \\
\text { with rounded apex, } \\
\text { strongly compressed, } \\
\text { only shallowly } \\
\text { divided in rounded } \\
\text { segments }\end{array}$ \\
\hline C. minor & $2 n=28^{2}$ & 12 & $0.8-1.3$ & Equal & No & $\begin{array}{l}\text { Alveolate, ridges low, } \\
\text { not wing-like }\end{array}$ \\
\hline C. paradoxa & $2 n=4 x^{3}$ & $4-6$ & $3.8-4.6$ & Unequal/irregular & Yes & $\begin{array}{l}\text { Irregularly cristate, } \\
\text { ridges wing-like, } \\
\text { deeply divided in } \\
\text { digitate expansions }\end{array}$ \\
\hline C. spetae & $2 n=4 \mathrm{x}^{3}$ & $17-24$ & $0.6-0.8$ & Equal & No & $\begin{array}{l}\text { Shallowly cristate- } \\
\text { alveolate, ridges low, } \\
\text { not wing-like }\end{array}$ \\
\hline
\end{tabular}

${ }^{1}$ Data partially or totally obtained from Sutton (Sutton 1988)

${ }^{2}$ Data partially obtained from Greuter and Rechinger (1967)

${ }^{3}$ Ploidy level inferred from flow cytometry measures

${ }^{4}$ Data obtained from Speta (1989)

${ }^{5} \mathrm{P}$. Carnicero, unpublished chromosome count

comprising C. acutiloba and C. minor with unresolved taxonomy. Furthermore, we propose to recognize $C$. microcalyx subsp. paradoxa at the species level. Here, we adopt the extant treatment that better reflects the evolutionary history of the lineages (Stuessy et al. 2014) and is also supported by diagnostic characters allowing the species' identification. However, our data also show the need of further studies to resolve the circumscription and adscription of C. acutiloba and $C$. minor. For these two taxa, current taxonomy does not reflect their evolution, but the resolution and sampling obtained here were not sufficient to propose a definitive solution. In addition, we confirm the previously suggested high diagnostic value of seed morphology in the group, as reported for other members of the tribe Antirrhineae (Elisens 1985; Vigalondo et al. 2015). 
Cymbalaria ebelii, endemic to the Skadar Lake area in Montenegro and Albania, did not group with any eastern Mediterranean species in the molecular analyses (Figs. 2, 3). Instead, it clustered with moderate support with the Sicilian endemic $C$. pubescens in the nrDNA analysis. Indeed, the area occupied by $C$. ebelii has closer floristic affinities with the Apennine Peninsula and the northern Balkan coast than with the southern Balkan Peninsula, the Aegean region and Anatolia (Takhtajan 1986). Our molecular results are congruent with other phylogenetic and phylogeographic studies in the area showing a strong biogeographic split between the northern and the southern Balkan Peninsula (Bardy et al. 2010; Surina et al. 2011; Hilpold et al. 2014) and with the hypothesis of a polyploid origin of $C$. ebelii and $C$. pubescens from a central Mediterranean ancestor (Carnicero et al. 2017). It remains open though, whether the two species originated from a single polyploid speciation and later diverged, or alternatively two independent events from closely related ancestors led to the origin of each of the species, and whether they originated through allo- or autopolyploidy. The separate position of the two species in the cpDNA tree (Fig. 3) as well as the ploidy level and distribution data available, suggests two independent events at two edges of the distribution of a $C$. muralis-related ancestor (i.e., southern Apennine Peninsula and northern Balkans). That would be congruent with the often observed pattern, that polyploidy often entails niche differentiation from their diploid relatives, and that polyploids rarely succeed where the parental species occur (Ramsey 2011; Baniaga et al. 2020). Morphologically, C. ebelii has unique oblong-ovoid seeds with a few low, scarcely anastomosed, longitudinal ridges (Speta 1986; Fig. 5) and capsules with folded pericarp reducing the space for the few seeds contained (Speta 1989). Thus, both molecular and morphological data support the recognition of $C$. ebelii as a separate species, which agrees with Speta (1986).

The recognition of $C$. microcalyx sensu Speta (1986) is supported by the nrDNA tree (Fig. 2) and morphological analyses (Fig. 4a). Our data further support to split it into two allopatric subspecies, i.e., subsp. microcalyx from the Peloponnese and subsp. heterosepala from western Crete. The moderately supported paraphyly of $C$. microcalyx subsp. microcalyx in the nrDNA tree (Fig. 2) suggests the Peloponnese as the ancestral area for the species followed by further dispersal to Crete leading to the origin of $C$. microcalyx subsp. heterosepala. This dispersal event might have been facilitated by the reduced distance between the continent and Crete during the marine regressions in the Pleistocene (Van Andel and Shackleton 1982). A similar case has been revealed in Campanula subgenus Roucela (Crowl et al. 2015). That distribution might explain the split of the two subspecies in the cpDNA tree: the position of $C$. microcalyx subsp. heterosepala might result from chloroplast capture after gene flow with other Aegean taxa (e.g., C. longipes or $C$. acutiloba subsp. dodekanesi, which occur in Creta as well, Fig. 3). Alternatively, that pattern could be explained by incomplete lineage sorting of ancestral variation in the cpDNA, which might be suggested by the close position of several taxa from completely different geographic regions (Fig. 3). These two patterns are more often impossible to disentangle with certainty (Pelser et al. 2010), and the lack of resolution of the cpDNA analyses prevents us from formulating further hypotheses. In contrast, $C$. microcalyx subsp. alba seems to have no taxonomic value, since (1) it is nested within $C$. microcalyx subsp. microcalyx and (2) its diagnostic characters (i.e., white flowers, smaller calix and longer spurs; Voliotis 1990, Tan and Iatrou 2001) can be observed in some individuals of other studied $C$. microcalyx subsp. microcalyx populations (P. Carnicero and Th. Constantinidis, pers. obs.). Seed characters best distinguish the two first mentioned subspecies. In $C$. microcalyx subsp. heterosepala at least some seeds form a concrescent mass, similarly as in $C$. longipes and $C$. microcalyx subsp. paradoxa, while in subsp. microcalyx the seeds are free (Fig. 5). Cymbalaria microcalyx subsp. heterosepala was originally described based on the different length of the lobes of the calyx (Rechinger 1943). This feature, however, is not even constant in all flowers of the holotype, and it is also found in some populations of $C$. microcalyx subsp. microcalyx (Greuter and Rechinger 1967). Therefore, it cannot be used as diagnostic character.

Cymbalaria longipes, C. acutiloba, C. minor and $C$. microcalyx subsp. paradoxa are clearly phylogenetically distinct from C. microcalyx (Fig. 2), but the lack of resolution both within the Circum-Aegean clade and with sister clades in both phylogenetic trees (Figs. 2, 3) prevents reconstruction of exact relationships. However, a few conclusions can be drawn. (1) The apparent split between $C$. microcalyx and that group, clearly shows that $C$. microcalyx subsp. paradoxa as circumscribed in C. microcalyx is misleading, and we therefore combine it at the species level (see Taxonomic treatment). Its phylogenetic position in both trees (Figs. 2, 3) and ploidy level (tetraploid based on RGS) indicates a polyploid origin of $C$. paradoxa, most probably with the diploid $C$. longipes as parental species. Polyploidy confers immediate isolation of the newly created lineage from their diploid relatives (Stebbins 1950; Grant 1981; Husband and Sabara 2003; Soltis et al. 2014), allowing its persistence as narrow endemic, which could otherwise be threatened by gene flow with the close populations of $C$. longipes in the island. Morphological data also support the strong relationship between $C$. longipes and $C$. paradoxa, by sharing similar capsules and seeds and their close position in the PCA (Fig. 4a). This adds a third polyploid speciation event in the genus Cymbalaria apart from those previously discussed (Carnicero et al. 2017). (2) The topology of the 
Circum-Aegean Clade in the nrDNA tree (Fig. 2) suggests a mainland origin in Greece followed by eastward dispersal, which first led to the origin of $C$. acutiloba subsp. dodekanesi in the Aegean Islands and subsequently to that of the Eastern Aegean Lineage (Fig. 2). However, due to the low support in the basal branches of the clade in the nrDNA tree and the low supports and incongruence observed in the cpDNA tree (Fig. 3), this hypothesis remains highly speculative. For the same reasons, and the unknown ploidy level of C. acutiloba subsp. acutiloba, the exact role of polyploidy in the group is still uncertain. Further studies at the populational level for eastern Aegean species combined with comprehensive RGS might contribute to disentangle the evolutionary history and systematics of this group. (3) The presence of $C$. acutiloba subsp. dodekanesi in both the western and the eastern Aegean Islands, which are considered to be floristically isolated by Rechinger's line (Rechinger 1950; Strid 1996), implies that the species crossed this biogeographic barrier, because it is much younger than the barrier (Carnicero et al. 2017). Rechinger's line has been partly confirmed as a genetic break zone with molecular data for some groups (Bittkau and Comes 2005; Crowl et al. 2015), but Rechinger (1950) himself reported that some taxa occur at both sides of the barrier (e.g., Campanula delicatula Boiss., Helichrysum orientale (L.) Gaertn.), suggesting a relative permeability. (4) Although Greuter and Rechinger (1967) considered $C$. longipes a "young" taxon of the $C$. microcalyx aggregate, ploidy data seriously challenge this statement as $C$. minor and C. paradoxa are tetraploid, while C. longipes is diploid (Greuter and Rechinger 1967). In addition, morphological divergence - it is the only glabrous taxon in the eastern Mediterranean region-suggests recognizing this taxon at the rank of species is appropriate. As mentioned above, the incongruence found between $\mathrm{cp}$ and nrDNA trees might either indicate gene flow and/or persistence of ancestral genetic variation (Figs. 2, 3).

As already shown in Carnicero et al. (2017), polyploid evolution played an important role in the evolution of the genus Cymbalaria, but its incidence on eastern species was only confirmed for $C$. ebelii. Our results stress its particular importance in the origin of the eastern taxa, by adding at least two confirmed polyploidy events to account for the origin of (1) the $C$. microcalyx-C. spetae clade and (2) $C$. paradoxa. At least a third event should be invoked to explain the tetraploid level of $C$. minor and C. acutiloba, but all the above-mentioned uncertainties regarding this group prevent the formulation of any detailed hypotheses.

\section{A new phylogenetically and morphologically well-delimited species}

The specimens of uncertain identity sampled from Taigetos in the southern Peloponnese constituted a monophyletic group in the molecular analyses (Figs. 2, 3), are morphologically well-distinguishable, and they are therefore below described as a new species. According the nrDNA, it is closely related to $C$. microcalyx, with which it shares ploidy level (Fig. 2), suggesting a common origin of both taxa through polyploid speciation. However, as mentioned above, the present data do not allow us to infer with certainty a single common origin of both taxa nor to identify the diploid ancestors. The close relatedness of the new species to the central Mediterranean diploids $C$. pallida and C. muralis subsp. visianii in the cpDNA analyses (Fig. 3), points them or a related ancestor as potential parental taxa, while $C$. microcalyx might have had a different uncertain origin, more distantly related to the extant central Mediterranean diploids. However, the observed pattern is congruent as well with a common origin and posterior divergence of the cpDNA, which could also be caused by gene flow of $C$. microcalyx with other eastern species. Morphologically, the specimens from Taigetos show several divergent characters with respect to all other eastern species, namely a higher number of leaf lobes, a longer calyx, a proportionally shorter spur, a high number of seeds per capsule and much smaller seeds (Figs. 5, 6 and Table 3). In fact, the most similar species to this entity is $C$. glutinosa Bigazzi $\&$ Raffaelli from the southern Apennine Peninsula, from which it can be clearly distinguished by having a longer calyx (2.3-3.7 $\mathrm{mm}$ vs. ca. $2 \mathrm{~mm}$ ) and often a longer corolla (9-14.2 mm vs. 6-12(13) mm). Moreover, these two species are distantly related and have different ploidy levels. Plants from Taigetos are tetraploid as inferred from RGS estimation, while C. glutinosa is diploid (Bigazzi and Raffaelli 2000). Altogether, this entity, which is currently known from only three populations, clearly deserves taxonomic recognition at the species level and is formally described below.

\section{Taxonomic treatment}

Cymbalaria paradoxa (Greuter) Carnicero, comb. \& stat nov. Basyonym: Cymbalaria microcalyx subsp. paradoxa Greuter, Willdenowia 8: 580. 1979.-HOLOTYPE: Dhodhekanisos; Kastellorhizo island group, Mejisti, S Harbour, 80-120 m a. s. 1., 15 Apr 1974, Greuter 11859 (W).

Cymbalaria spetae Carnicero, sp. nov.- HOLOTYPE: Greece: Peloponnese, Lakonia, Trypi, road to Kalamata, tunnel excavated in the rock, cracks in shady limestone rocks, 780 m a. s. 1., 8 Jun 2014, P. Carnicero 1074 (BC 955798!; isotype W!) (Fig. 7).

Etymology: Named after the late Franz Speta, in recognition of his outstanding work on the taxonomy of Cymbalaria. 
Fig. 6 a-c Cymbalaria spetae in its natural habitat. $\mathbf{d}$ Type locality

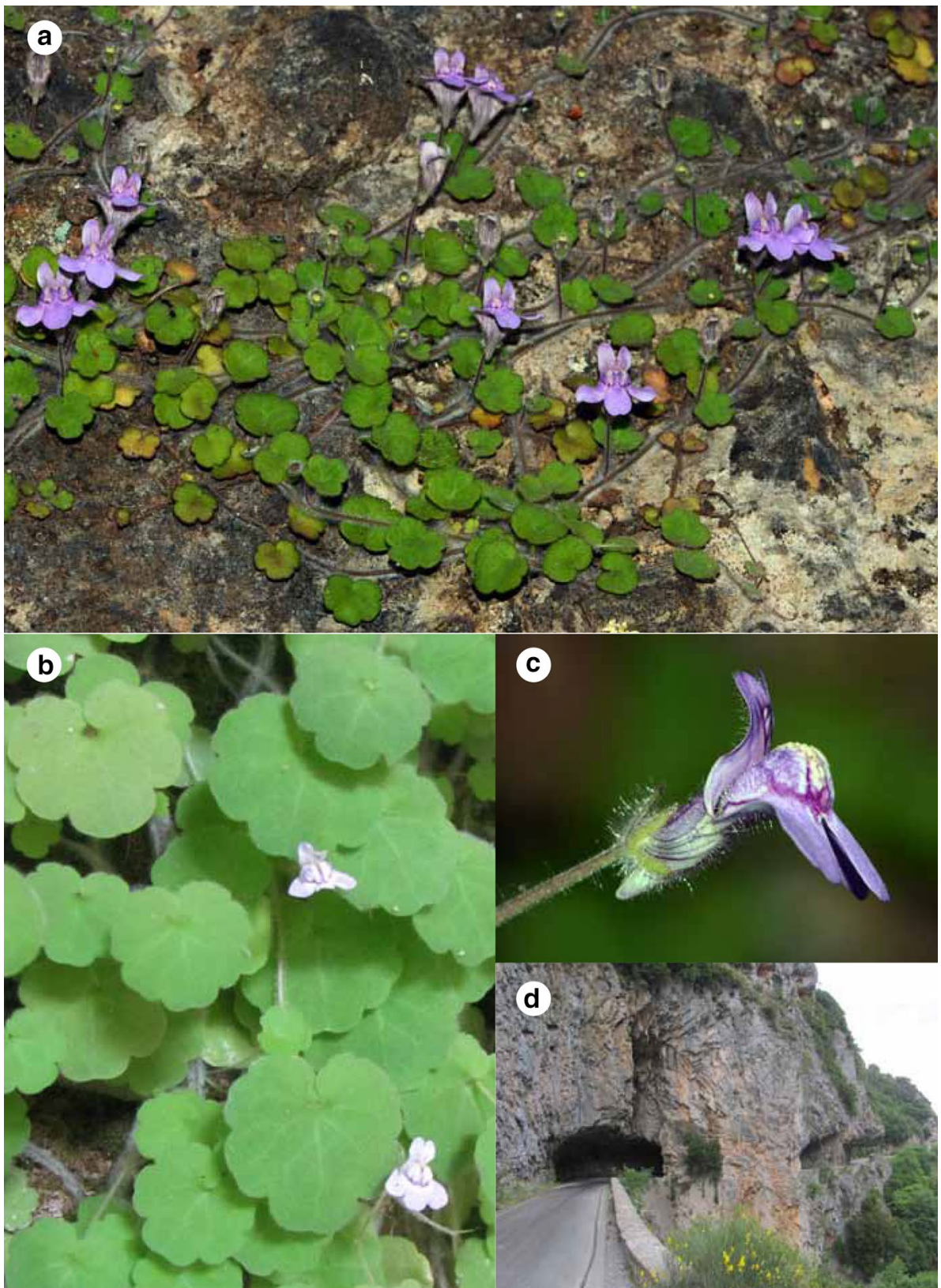

Description: Perennial herb, villous to lanate in all vegetative organs, indumentum composed of eglandular trichomes and glandular trichomes. Stems trailing, procumbent or decumbent, up to $100 \mathrm{~cm}$ long, villous to lanate. Leaves $13.4-42 \mathrm{~mm}$ in diameter, opposite to alternate, petiolate, reniform to orbicular, (5)7-11 lobed, villous on both surfaces. Flowers zygomorphic, pedicellate, solitary in leaf axils; pedicels 15-29(37) $\mathrm{mm}$ long in flower, 25-37 mm long in fruit, puberulent to villous, with decreasing density of eglandular trichomes toward the apex and high density of short glandular hairs in the upper part. Calyx lobes subequal, $2.3-3.7 \mathrm{~mm}$ long in flower, $3.3-3.9 \mathrm{~mm}$ long in fruit, lanceolate, villous. Corolla $9-14.2 \mathrm{~mm}$ long from the palate to the tip of the spur, pink to violet, palate yellow to pale violet and occasionally with purple veins; tube $2.5-4.9 \mathrm{~mm}$ wide; upper lip 6.2-9.6×5-6.8 mm with purple veins, sinus 1.7-3.1 mm long; lower lip 9.4-12.2(16.8) mm wide, sinus 3-4.7 mm long; spur 1.3-3.2 $\times 0.9-2.2 \mathrm{~mm}$. Capsule 2.2 $3.0 \times 2.5-3.3 \mathrm{~mm}$, spherical, glandular-pubescent, glandular trichomes up to $0.5 \mathrm{~mm}$ long, loculi equal, each loculus dehiscing with irregular valves. Seeds $17-25$ per capsule, 0.6-0.8 mm long, equal-sized, spherical to ovoid, not forming a concrescent mass, black; surface shallowly cristatealveolate; testa cells polygonal with anastomosed anticlinal walls, periclinal walls of cells of the alveolus bearing a median papilla. 


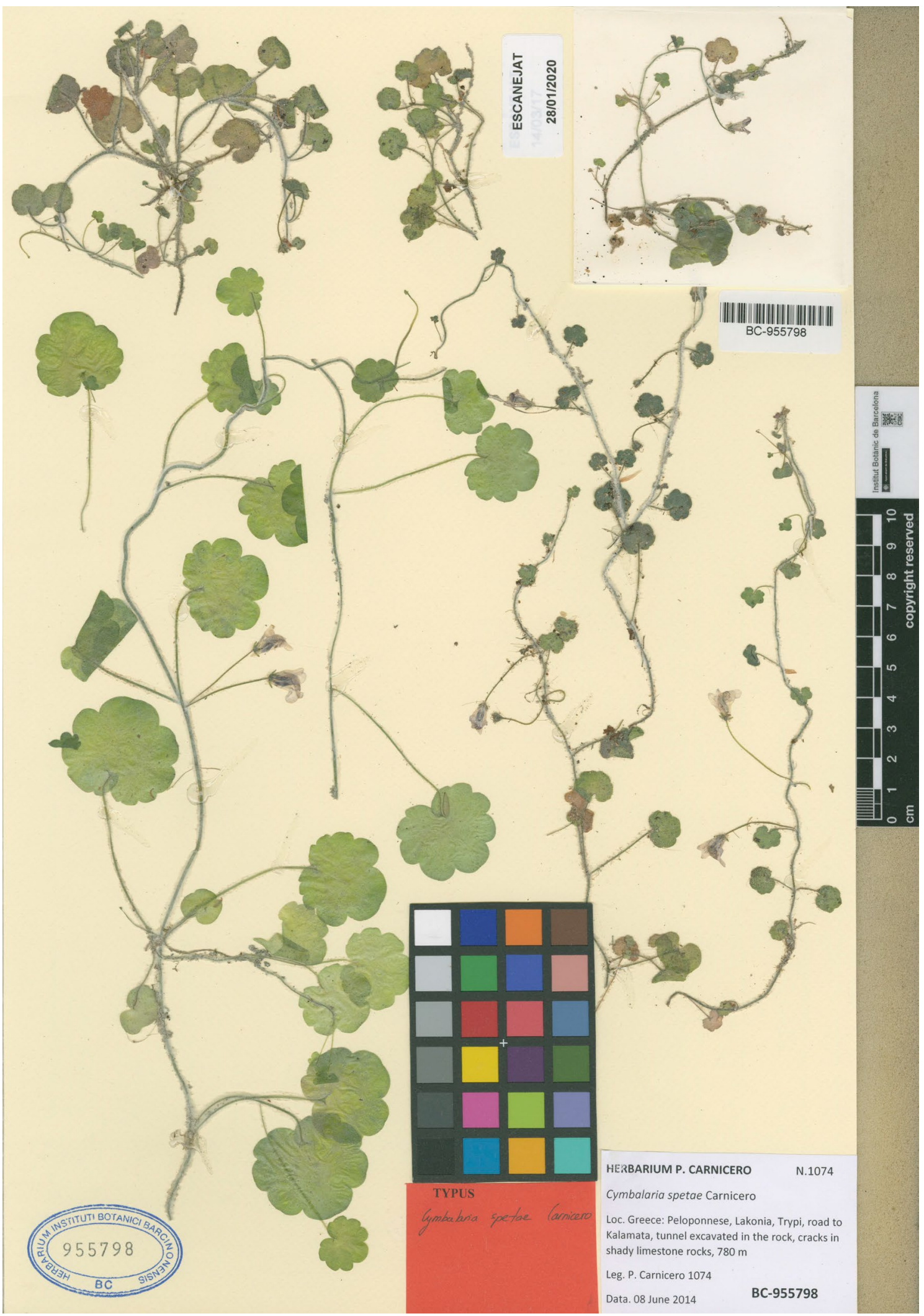

Fig. 7 Holotype of Cymbalaria spetae. Greece: Peloponnese, Lakonia, Trypi, road to Kalamata, tunnel excavated in the rock, cracks in shady limestone rocks, $780 \mathrm{~m}$ a. s. 1, 8 Jun 2014, P. Carnicero 1074 (BC 955798) 
Diagnosis: The new species differs from other eastern Mediterranean species (C. acutiloba, $C$. ebelii, $C$. longipes, $C$. microcalyx and $C$. minor) in its longer calyx lobes (2.3$3.7 \mathrm{~mm}$ long in flower, $3.3-3.9 \mathrm{~mm}$ long in fruit), smaller and more numerous seeds per capsule (0.6-0.8 mm long, 17-24 seeds/capsule) and a proportionally shorter and wider spur. It differs from the morphologically similar, but not closely related $C$. glutinosa in having a longer calyx $(C$. spetae: 2.3-3.7 mm vs. C. glutinosa ca. $2 \mathrm{~mm}$, Bigazzi and Raffaelli, 2000: 200) and a generally longer corolla (C. spetae: 9-14.2 mm long vs. C. glutinosa: 6-12(13) mm long, Bigazzi and Raffaelli 2000: 200).

Chromosome number: Likely $2 n=4 \mathrm{x}$; as inferred from RGS.

Habitat and altitudinal range: Rock crevices of shady limestone cliffs, 200-800 m a. s. 1 .

Distribution area: Local endemic of the Taigetos mountain range in the Peloponnese (only three populations known).

\section{Identification key to eastern Mediterranean Cymbalaria taxa}

1a Leaves and stems glabrous or only with sparse hairs on young organs 2

2a Capsule dehiscent. More than 10 seeds per capsule. Seeds $0.9-1.3 \mathrm{~mm}$ long, free from each other C. muralis subsp. muralis

2b Capsule indehiscent. 2-6 seeds per capsule. Seeds 3.5-5.6 mm long, forming a concrescent mass in each loculus C. longipes

1b Stems hairy ......................................................... 3

3a Calyx lobes 2.3-3.7 mm long in flower. 17-24 seeds per capsule. Seeds $0.6-0.8 \mathrm{~mm}$ long C. spetae

3 b Calyx lobes $0.5-2 \mathrm{~mm}$ long in flower. 2-14 seeds per capsule. Seeds $0.8-5.6 \mathrm{~mm}$ long .............................. 4

4a Capsule indehiscent, 7.9-9.2 mm long. All seeds forming a concrescent mass .......................... C. paradoxa

4b Capsule dehiscent, 2.5-6.2 mm long. Most often seeds well separated from each other ....

5

5a Capsule dehiscing along undulated longitudinal ridges. Seeds cristate with low longitudinal ridges, scarcely anastomosed C. ebelii

5b Capsule dehiscing differently. Seeds alveolate or cristate with wing-like ridges, markedly anastomosed ........... 6

6a Seeds within a capsule all equal-sized, $0.8-1.3 \mathrm{~mm}$ long, alveolate C. minor

$6 \mathrm{~b}$ Seeds of unequal size within a capsule, $0.9-4.8 \mathrm{~mm}$ long, alveolate or irregularly cristate .. 7

7a Up to 14 seeds per capsule. Seeds alveolate or irregularly cristate with ridges deeply divided in digitate expansions with rounded apex or with numerous triangular tips ... 8 7b 4-10 seeds per capsule. Seeds irregularly cristate with ridges shallowly divided, segments with a rounded ape

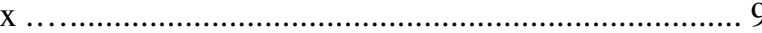

8a All seeds irregularly cristate with wing-like ridges with numerous triangular tips

C. acutiloba subsp. acutiloba

$8 \mathrm{~b}$ Basal seeds irregularly cristate with wing-like ridges with rounded apex, otherwise alveolate without winglike ridges C. acutiloba subsp. dodekanesi

9a Seeds clearly separated from each other, never forming a concrescent mass ... C. microcalyx subsp. microcalyx

9b At least some seeds hard to separate from each other, forming a concrescent mass

C. microcalyx subsp. heterosepala

\section{Information on Electronic Supplementary Materi- als}

Online Resource 1. List of specimens used in molecular analyses with information on the specimen codes used in the text and figures, locality, herbarium voucher and accession numbers.

Online Resource 2. Characteristics of sequences and results of phylogenetic analyses.

Online Resource 3. List of additional specimens examined.

Online Resource 4. Concatenated nrDNA alignment used for the phylogenetic analyses in nexus format.

Online Resource 5. Concatenated cpDNA alignment used for the phylogenetic analyses in nexus format.

Supplementary material 1Supplementary material 2Supplementary material 3 Supplementary material 4 Supplementary material 5Acknowledgements This research was funded in part by the Spanish government (CGL2010-18631/BOS and the Flora iberica project, CGL2011-28613-C03-01) as well as by the Catalan government (2014-SGR 514 and 2017-SGR1116). We are grateful to the herbaria that provided material or kindly sent scanned images for examination (ATHU, B, BM, E, G, K, FI, W) and specially to the team of BC. We are also grateful to R. Vilatersana for collecting material from the Aegean Islands. We thank P. Schönswetter for valuable comments on the final manuscript. Pau Carnicero benefited from the support of a PIF Ph.D. student fellowship from the Universitat Autònoma de Barcelona. We thank M. Gassner from the Institute of Botany of Innsbruck for performing relative genome size measures. We thank the gardeners of the Botanical Garden of Barcelona for successfully cultivating accessions of Cymbalaria. We are also grateful to A. Crowl and an anonymous reviewer for their constructive and helpful comments on the first version of the manuscript.

Authors' contributions Pau Carnicero, Llorenç Sáez, Núria GarciaJacas and Mercè Galbany-Casals conceived the project. Pau Carnicero and Theophanis Constantinidis conducted the field samplings. Pau Carnicero, Núria Garcia-Jacas and Mercè Galbany-Casals designed and conducted the analyses. All authors contributed to the interpretation of results. Pau Carnicero and Mercè Galbany-Casals drafted the manuscript. All authors revised the manuscript.

Funding Open Access funding provided by University of Innsbruck and Medical University of Innsbruck. This research was funded in part by the Spanish government (CGL2010-18631/BOS and the Flora iberica project, CGL2011-28613-C03-01) as well as by the Catalan government (2014-SGR 514 and 2017-SGR1116). Pau Carnicero benefited 
from the support of a PIF Ph.D. student fellowship from the Universitat Autònoma de Barcelona.

Availability of data and material The DNA sequence generated and analyzed during the current study is available in GenBank (http://www. ncbi.nlm.nih.gov/genbank/). Other datasets (alignment, morphological data, morphometric analyses scripts) are available from the corresponding author on reasonable request.

\section{Compliance with ethical standards}

Conflicts of interest The authors declare that they have no conflict of interest.

Open Access This article is licensed under a Creative Commons Attribution 4.0 International License, which permits use, sharing, adaptation, distribution and reproduction in any medium or format, as long as you give appropriate credit to the original author(s) and the source, provide a link to the Creative Commons licence, and indicate if changes were made. The images or other third party material in this article are included in the article's Creative Commons licence, unless indicated otherwise in a credit line to the material. If material is not included in the article's Creative Commons licence and your intended use is not permitted by statutory regulation or exceeds the permitted use, you will need to obtain permission directly from the copyright holder. To view a copy of this licence, visit http://creativecommons.org/licenses/by/4.0/.

\section{References}

Abràmoff MD, Magalhães PJ, Ram SJ (2004) Image processing with imageJ. Biophotonics Int 11:36-41. https://doi. org/10.1117/1.3589100

Baniaga AE, Marx HE, Arrigo N, Barker MS (2020) Polyploid plants have faster rates of multivariate niche differentiation than their diploid relatives. Ecol Lett 23:68-78. https://doi.org/10.1111/ ele. 13402

Bardy KE, Albach DC, Schneeweiss GM, Fischer MA, Schönswetter $\mathrm{P}$ (2010) Disentangling phylogeography, polyploid evolution and taxonomy of a woodland herb (Veronica chamaedrys group, Plantaginaceae s.1.) in southeastern Europe. Molec Phylogen Evol 57:771-786. https://doi.org/10.1016/j.ympev.2010.06.025

Bigazzi M, Raffaelli M (2000) Taxonomy of two Cymbalaria species (Scrophulariaceae) endemic to Italy: $C$. glutinosa sp. nov. and $C$. pubescens (J. \& C. Presl) Cuf. Webbia 54:201-205. https://doi. org/10.1080/00837792.2000.10670679

Bittkau C, Comes HP (2005) Evolutionary processes in a continental island system: molecular phylogeography of the Aegean Nigella arvensis alliance (Ranunculaceae) inferred from chloroplast DNA. Molec Ecol 14:4065-4083. https://doi.org/10.1111/j.1365294X.2005.02725.x

Carnicero P, Sáez L, Garcia-Jacas N, Galbany-Casals M (2017) Different speciation types meet in a Mediterranean genus: the biogeographic history of Cymbalaria (Plantaginaceae). Taxon 66:393407. https://doi.org/10.12705/662.7

Carnicero P, Schönswetter P, Fraga Arguimbau P, Garcia-Jacas N, Sáez L, Galbany-Casals M (2018) Phylogeography of western Mediterranean Cymbalaria (Plantaginaceae) reveals two independent long-distance dispersals and entails new taxonomic circumscriptions. Sci Rep 8:18079. https://doi.org/10.1038/s41598-018-36412 $-1$

Carnicero P, Schönswetter P, Garcia-Jacas N, Galbany-Casals M (2019) Is there a need for accepting paraphyletic taxa? A case study in the
Sardinian endemic Cymbalaria muelleri (Plantaginaceae). Bot J Linn Soc 191:325-338. https://doi.org/10.1093/botlinnean/boz052

Castresana J (2000) Selection of conserved blocks from multiple alignments for their use in phylogenetic analysis. Molec Biol Evol 17:540-552. https://doi.org/10.1093/oxfordjournals.molbe v.a026334

Crowl AA, Visger CJ, Mansion G, Hand R, Wu HH, Kamari G, Phitos D, Cellinese N (2015) Evolution and biogeography of the endemic Roucela complex (Campanulaceae: Campanula) in the Eastern Mediterranean. Ecol Evol 5:5329-5343. https://doi.org/10.1002/ ece 3.1791

Cufodontis G (1936) Revisione monografica delle Linaria appartenenti alla sez. Cymbalaria Chav Arch Bot 12:135-158

Cufodontis G (1947) Die Gattung Cymbalaria Hill. Nachträge und Zusammenfassung. Bot Not 2:135-156

Dimopoulos P, Raus T, Bergmeier E, Constantinidis T, Iatrou G, Kokkini S, Strid A, Tzanoudakis D (2013) Vascular plants of Greece: an annotated checklist. Botanischer Garten und Botanisches Museum Berlin-Dahlem, Berlin

Doyle JJ, Doyle JL (1987) A rapid DNA isolation procedure for small quantities of fresh leaf tissue. Phytochem Bull 19:11-15

Eldenäs P, Källersjö M, Anderberg A (1999) Phylogenetic placement and circumscription of tribes Inuleae s. str. and Plucheeae (Asteraceae): evidence from sequences of chloroplast gene $n d h \mathrm{~F}$. Molec Phylogen Evol 13:50-58. https://doi.org/10.1006/mpev.1999.0635

Elisens WJ (1985) The systematic significance of seed coat anatomy among New World species of tribe Antirrhineae (Scrophulariaceae). Syst Bot 10:282-292. https://doi.org/10.2307/2418592

Fady-Welterlen B (2005) Is there really more biodiversity in Mediterranean forest ecosystems? Taxon 54:905-910. https://doi. org $/ 10.2307 / 25065477$

Frajman B, Rešetnik I, Weiss-Schneeweiss H, Ehrendorfer F, Schönswetter P (2015) Cytotype diversity and genome size variation in Knautia (Caprifoliaceae, Dipsacoideae). BMC Evol Biol 15:140. https://doi.org/10.1186/s12862-015-0425-y

Galbany-Casals M, Garcia-Jacas N, Sáez L, Benedí C, Susanna A (2009) Phylogeny, biogeography, and character evolution in Mediterranean, Asiatic, and Macaronesian Helichrysum (Asteraceae, Gnaphalieae) inferred from nuclear phylogenetic analyses. Int J Pl Sci 170:365-380. https://doi.org/10.1086/596332

Galbany-Casals M, Carnicero-Campmany P, Blanco-Moreno JM, Smissen RD (2012) Morphological and genetic evidence of contemporary intersectional hybridisation in Mediterranean Helichrysum (Asteraceae, Gnaphalieae). Pl Biol 14:789-800. https:// doi.org/10.1111/j.1438-8677.2012.00568.x

Ghebrehiwet M, Bremer B, Thulin M (2000) Phylogeny of the tribe Antirrhineae (Scrophulariaceae) based on morphological and $n d h \mathrm{~F}$ sequence data. Pl Syst Evol 220:223-239. https://doi. org/10.1007/BF00985047

Grant V (1981) Plant speciation, 2nd edn. Columbia University Press, New York

Greuter W (1979) Flora and phytogeography of Kastellorizo (Dhodhekanisos, Greece). 1. An annotated catalogue of the vascular plant taxa. Willdenowia 8:531-611

Greuter W, Rechinger KH (1967) Cloria Kithereia. Boissiera 13:22-196

Guzmán B, Gómez JM, Vargas P (2015) Bees and evolution of occluded corollas in snapdragons and relatives (Antirrhineae). Perspect Pl Ecol Evol Syst 17:467-475. https://doi.org/10.1016/j. ppees.2015.07.003

Hilpold A, Vilatersana R, Susanna A, Meseguer AS, Boršić I, Constantinidis T, Filigheddu R, Romaschenko K, Suárez-Santiago VN, Tugay O, Uysal T, Pfeil BE, Garcia-Jacas N (2014) Phylogeny of the Centaurea group (Centaurea, Compositae)-Geography is a better predictor than morphology. Molec Phylogen Evol 77:195215. https://doi.org/10.1016/j.ympev.2014.04.022 
Husband BC, Sabara HA (2003) Reproductive isolation between autotetraploids and their diploid progenitors in fireweed, Chamerion angustifolium (Onagraceae). New Phytol 161:703-713. https:// doi.org/10.1046/j.1469-8137.2004.00998.x

Kim K, Jansen R (1995) $n d h F$ sequence evolution and the major clades in the sunflower family. Proc Natl Acad Sci 92:10379-10383

Koutecký P (2015) MorphoTools: a set of R functions for morphometric analysis. Pl Syst Evol 301:1115-1121. https://doi.org/10.1007/ s00606-014-1153-2

Lanfear R, Calcott B, Ho SYW, Guindon S (2012) Partitionfinder: combined selection of partitioning schemes and substitution models for phylogenetic analyses. Molec Biol Evol 29:1695-1701. https ://doi.org/10.1093/molbev/mss020

Larkin MA, Blackshields G, Brown NP, Chenna R, McGettigan PA, McWilliam H, Valentin F, Wallace IM, Wilm A, Lopez R, Thompson JD, Gibson TJ, Higgins DG (2007) Clustal W and Clustal X version 2.0. Bioinformatics 23:2947-2948. https://doi. org/10.1093/bioinformatics/btm404

Lazarević M, Kuzmanović N, Lakušić D, Alegro A, Schönswetter P, Frajman B (2015) Patterns of cytotype distribution and genome size variation in the genus Sesleria Scop. (Poaceae). Bot J Linn Soc 179:126-143. https://doi.org/10.1111/boj.12306

Leitch IJ, Bennett MD (2004) Genome downsizing in polyploid plants. Biol J Linn Soc 82:651-663. https://doi.org/10.111 1/j.1095-8312.2004.00349.x

Manafzadeh S, Salvo G, Conti E (2014) A tale of migrations from east to west: the Irano-Turanian floristic region as a source of Mediterranean xerophytes. J Biogeogr 41:366-379. https://doi. org/10.1111/jbi.12185

Markos S, Baldwin BG (2001) Higher-level relationships and major lineages of Lessingia (Compositae, Astereae) based on nuclear rDNA internal and external transcribed spacer (ITS and ETS) sequences. Syst Bot 26:168-183

Maroulis G, Georgiadis T (2005) The vegetation of supra-forest meadows and rock crevices of Mount Erimanthos (NW Peloponnisos, Greece). Fitosociologia 42:33-56

Pelser PB, Kennedy AH, Tepe EJ, Shidler JB, Nordenstam B, Kadereit JW, Watson LE (2010) Patterns and causes of incongruence between plastid and nuclear Senecioneae (Asteraceae) phylogenies. Amer J Bot 97:856-873

Polunin O (1980) Flowers of Greece and the Balkans. Oxford University Press, New York

Ramsey J (2011) Polyploidy and ecological adaptation in wild yarrow. Proc Natl Acad Sci USA 108:7096-7101. https://doi.org/10.1073/ pnas. 1016631108

Rechinger KH (1943) Neue Beiträge zur Flora von Kreta. Denkschr Akad Wiss Wien, Math-Naturwiss K1 105:1-184

Rechinger KH (1950) Grundzüge der Pflanzenverbreitung in der Aegäis I - III. Vegetatio 2:55-119, 239-308, 365-386

Ronquist F, Teslenko M, van der Mark P, Ayres DL, Darling A, Höhna S, Larget B, Liu L, Ma Suchard, Huelsenbeck JP (2012) MrBayes 3.2: efficient Bayesian phylogenetic inference and model choice across a large model space. Syst Biol 61:539-542. https://doi. org/10.1093/sysbio/sys029

Ronquist F, Huelsenbeck JP, Teslenko M, Nylander JAA (2020) MrBayes version 3.2 manual: tutorials and model summaries. Available at: https://github.com/NBISweden/MrBayes. Accessed May 2020

Roquet C, Sanmartín I, Garcia-Jacas N, Sáez L, Susanna A, Wikström N, Aldasoro JJ (2009) Reconstructing the history of Campanulaceae with a Bayesian approach to molecular dating and dispersal-vicariance analyses. Molec Phylogen Evol 52:575-587. https ://doi.org/10.1016/j.ympev.2009.05.014

Sáez L, Crespo MB (2005) A taxonomic revision of the Linaria verticillata group (Antirrhineae, Scrophulariaceae). Bot J Linn Soc 148:229-244
Schwarz G (1978) Estimating the dimension of a model. Ann Statist 6:461-464. https://doi.org/10.1214/aos/1176344136

Shaw J, Lickey E, Schilling EE, Small RL (2007) Comparison of whole chloroplast genome sequences to choose noncoding regions for phylogenetic studies in angiosperms: the tortoise and the hare III. Amer J Bot 94:275-288. https://doi.org/10.3732/ajb.94.3.275

Simmons MP, Ochoterena H (2000) Gaps as characters in sequencebased phylogenetic analyses. Syst Biol 49:369-381. https://doi. org/10.1080/10635159950173889

Soltis DE, Visger CJ, Soltis PS (2014) The polyploidy revolution then and now: Stebbins revisited. Amer J Bot 101:1057-1078. https:// doi.org/10.3732/ajb.1400178

Speta F (1986) Heterokarpidie, Dehiszenz, Heterospermie und basifixe Samen bei Cymbalaria Hill (Scrophulariaceae) und systematische Schlußfolgerungen. Phyton 26:23-57

Speta F (1989) Zur Morphologie und Karyologie von Cymbalaria ebelii Cufod. (Scrophulariaceae). Phyton 29:247-254

Stebbins GL (1950) Variation and evolution in plants. Oxford University Press, London

Strid A (1996) Phytogeographia Aegaea and the Flora Hellenica database. Ann Naturhist Mus Wien, B 98:279-289

Stuessy TF, Crawford DJ, Soltis DE, Soltis PS (2014) Plant systematics: the origin, interpretation, and ordering of plant biodiversity. Koeltz Scientific Books, Königstein

Suda J, Trávníček P (2006) Estimation of relative nuclear DNA content in dehydrated plant tissues by fow cytometry. In: Robinson JP, Darzynkiewicz Z, Dobrucki J, Hyun WC, Nolan JP, Orfao A, Rabinovich PS (eds) Current protocols in cytometry. Wiley, New York. https://doi.org/10.1002/0471142956.cy0730s38

Suda J, Weiss-Schneeweiss H, Tribsch A, Schneeweiss GM, Travnicek P, Schönswetter P (2007) Complex distribution patterns of di-, tetra-, and hexaploid cytotypes in the European high mountain plant Senecio carniolicus (Asteraceae). Amer J Bot 94:13911401. https://doi.org/10.3732/ajb.94.8.1391

Sun Y, Skinner D, Liang G, Hulbert S (1994) Phylogenetic analysis of Sorghum and related taxa using internal transcribed spacers of nuclear ribosomal DNA. Theor Appl Genet 89:26-32. https://doi. org/10.1007/BF00226978

Surina B, Schönswetter P, Schneeweiss GM (2011) Quaternary range dynamics of ecologically divergent species (Edraianthus serpyllifolius and E. tenuifolius, Campanulaceae) within the Balkan refugium. J Biogeogr 38:1381-1393. https://doi.org/10.111 1/j.1365-2699.2011.02493.x

Sutton DA (1988) A revision of the tribe Antirrhineae. British Museum (Natural History), London

Swofford D (2002) PAUP*: Phylogenetics analysis using parsimony (*and other methods), version 4.0b10. Sinauer, Sunderland

Takhtajan A (1986) Floristic regions of the world. University of California Press, Berkeley

Talavera G, Castresana J (2007) Improvement of phylogenies after removing divergent and ambiguously aligned blocks from protein sequence alignments. Syst Biol 56:564-577. https://doi. org/10.1080/10635150701472164

Tamura K, Stecher G, Peterson D (2013) MEGA6: molecular evolutionary genetics analysis version 6.0. Molec Biol Evol 30:27252729. https://doi.org/10.1093/molbev/mst197

Tan K, Iatrou G (2001) Endemic plants of Greece: the Peloponnese. Gad Publishers Ltd, Copenhagen

Tel-Zur N, Abbo S, Myslabodski D, Mizrahi Y (1999) Modified CTAB procedure for DNA isolation from epiphytic cacti of the genera Hylocereus and Selenicereus (Cactaceae). Pl Molec Biol 17:249-254

Temsch EM, Greilhuber J (2010) Genome size in Dipsacaceae and Morina longifolia (Morinaceae). Pl Syst Evol 289:45-56. https:// doi.org/10.1007/s00606-010-0330-1 
Thompson JD (2005) Plant evolution in the Mediterranean. Oxford University Press, Oxford

Van Andel TH, Shackleton JC (1982) Late paleolithic and mesolithic coastlines of Greece and the Aegean. J Field Archaeol 9:445-454

Vargas P, Rosselló JA, Oyama R, Güemes J (2004) Molecular evidence for naturalness of genera in the tribe Antirrhineae (Scrophulariaceae) and three independent evolutionary lineages from the New World and the Old. Pl Syst Evol 249:151-172. https:// doi.org/10.1007/s00606-004-0216-1

Vigalondo B, Fernández-Mazuecos M, Vargas P, Sáez L (2015) Unmasking cryptic species: morphometric and phylogenetic analyses of the Ibero-North African Linaria incarnata complex. Bot J Linn Soc 177:395-417

Voliotis D (1990) Neue Materialien und kritische Kommentare zu "Floram Hellenicam” (Griechenland). Ann Mus Goulandris 8:223-236
Wu H, Guiot J, Brewer S, Guo Z (2007) Climatic changes in Eurasia and Africa at the last glacial maximum and mid-Holocene: reconstruction from pollen data using inverse vegetation modelling. Clim Dynam 29:211-229. https://doi.org/10.1007/s0038 2-007-0231-3

Publisher's Note Springer Nature remains neutral with regard to jurisdictional claims in published maps and institutional affiliations. 